\title{
Contradictions and Concordances in American Colonization Models
}

\author{
Dennis H. O'Rourke
}

Published online: 21 April 2011

(C) Springer Science+Business Media, LLC 2011

\begin{abstract}
The traditional view of American colonization during the late Pleistocene has largely been conditioned on early conceptions of the timing and extent of continental glaciations and the age and distribution of archeological sites. A review of newer, high resolution genetic data, both from modern populations and ancient DNA samples, along with the emergence of several early archeological sites in both North and South America, and reconsiderations of the glacial dynamics in North America indicate that some aspects of the traditional view need reconsideration. It seems obvious from archeological data that a preglacial occupation of the Americas needs to be closely examined. Accumulating molecular genetic data raises new questions about the timing and population size of the initial colonization(s), while a closer examination of glacial models suggests that a number of routes into the Americas may have been available until fairly late in the last glacial cycle.
\end{abstract}

Keywords American colonization - Genetic models . Glacial paleoecology · Demography

\section{Introduction}

For nearly half a century, the received wisdom regarding the initial colonization of the Western Hemisphere was the following: small bands of large-game hunters followed their prey across the Bering Land Bridge from Asia, moved south through the ice-free corridor separating retreating continental glaciers and, finding themselves in the midst of a large

D. H. O'Rourke $(\bowtie)$

University of Utah,

Salt Lake City, UT, USA

e-mail: orourke@anthro.utah.edu continent uninhabited by other people, very rapidly migrated to the farthest reaches of the American continents while expanding dramatically in population size. Two additional "presumptions" were also part of this traditional colonization scenario. The first is that the original colonists were small in number such that the original colonization represented a population bottleneck and second, the colonization itself was essentially coincident with the end of the last glacial cycle. The early appreciation that the Clovis archeological tradition was widespread in North America shortly after the Last Glacial Maximum (LGM), and that no other widespread archeological tradition predated Clovis, led logically to the inference that either the original colonists were the bearers of the Clovis stone tool tradition, or their immediate descendants developed and spread it throughout North America shortly after arrival.

This "Clovis first" view of the initial colonization of the Americas was the dominant paradigm for American colonization for decades. By the late twentieth century, however, questions were raised about the primacy of Clovis at colonization (e.g., Meltzer 2009; Adovasio and Pedler 2004; Dillehay 1997). Nevertheless, the view that the early colonists arrived immediately post-LGM, were few in number (bottleneck), and dispersed very rapidly throughout the Americas was unaltered. This view was consistent with early paleoecological data on the existence and nature of the Beringian land connection between Asia and North America during the LGM, with the age and distribution of archeological sites in the Americas, as well as with the demonstration of genetic and morphological similarity of Native American populations to those of Asia. However, over the past decade or so, discoveries in archeology, new data, and understanding of the paleoecology of Beringia including the timing and extent of glacial advances and retreats, the distribution of glacial refugia, and especially the greater resolution provided by the molecular genetic 
characterizations of modern and ancient indigenous populations have raised questions about various aspects of the traditional view of American colonization.

In this essay, I do not propose to provide a detailed review of either the archeological record of the Americas, patterns of genetic variation that characterize indigenous American populations and that inform us about the genetic history of a hemisphere, or of newer data that inform us about the late Pleistocene ecologies and glaciology of the Americas. Such comprehensive and detailed reviews from several perspectives are already available (Goebel et al. 2008; Meltzer 2009; Dillehay 2009; Madsen 2004; Dixon 2001; O’Rourke and Raff 2010; Kemp and Schurr 2010; Achilli et al. 2008; Tamm et al. 2007; Yang et al. 2010; Marshall et al. 2002; Alfimov and Berman 2001; Siddall et al. 2008). Nor will I review the substantial literature on morphological variation in prehistoric America that bears on the issue. Excellent reviews of these materials also are available and covered in this issue (Perez et al. 2009; González-José et al. 2008; Pucciarelli et al. 2006). Consequently, this is not meant as an exhaustive review of the relevant literature.

Rather, it is my aim to highlight aspects of data and analyses in three different areas of research-archaeology, genetics, and paleoecology-compare the inferences derived from each of these in turn and contrast the inferences drawn with the traditional, historical view of American colonization. To what degree do the data emerging from paleoecological research in the late Pleistocene of North America, from archeological excavations throughout the Americas, and from modern and ancient genetic studies on indigenous populations in the Americas and Asia support the traditional view, and in what ways do they provide compelling challenges to that view? In what ways do the newer, higher resolution data contradict past conceptions, and in what ways do they provide corroboration of traditional explanations for American origins? Although my goal is to be synthetic with respect to different research approaches, it is necessary to frame the discussion with brief descriptions of new research in each area and then emphasize points of intersection.

\section{Archeology}

It is beyond the scope of this review to evaluate the competing arguments regarding the primacy of Clovis as a marker of the first arrivals on the North American continent. This debate has been effectively reviewed by others (e.g., Goebel et al. 2008; Meltzer 2009, Adovasio and Pedler 2004). It will suffice to say that there are now a number of archeological sites in both North and South America that appear to predate the Clovis occupation, an archeological lithic tradition which may have had a shorter temporal span than previously assumed (Waters and Stafford 2007). Irrespective of what material culture is ultimately attributed to the first colonists, what is most relevant to this discussion is the antiquity and geographic distribution of the earliest known archeological sites in the Americas.

Under the generally accepted model of American colonization, populations entered the Western Hemisphere via the Beringian land bridge shortly after the LGM, and rapidly dispersed southward through an ice-free corridor between retreating glacial masses. A logical expectation is that the oldest sites should correlate with the earliest occupation. Thus, we would expect to find the earliest sites in the north, particularly in northern and western Beringia with later sites situated farther south, reflecting the southward journey of the initial migrants. Obviously, this model predicts that the earliest evidence of occupation of the Americas would be found in North America and only later occupations would be found in South America. As is well known, such a temporal distribution of sites is not readily apparent. The oldest reported site in northern North America, Swan Point in Alaska (Holmes and Crass 2003), is approximately 14,000 years old, coeval with the Monte Verde site in South America (Dillehay 1997). It is worth noting that a number of early sites (e.g., more than 12,000 years ago; Taima-Taima, Pedra Furada, Santana do Riacho, Lapa do Boquete, among others) have been reported in South America (Dillehay 1997, 2009; Goebel et al. 2008). These sites are often dismissed by most North America archeologists but not by European colleagues. The first point to be made then is that the geographic distribution of known early archeological sites does not readily conform to the distribution predicted from the traditional colonization scenario, even when restricting attention to the widely accepted sites and dates across the Americas. And this is even less true if some of the more tenuous claims to great antiquity ultimately are confirmed. The equivalence in age of the earliest sites in both North and South America, of course, may be simply the result of sampling the archeological record. A closer examination of regional sites might prove more illuminating.

Limiting attention just to North America, the temporalspatial distribution of sites at first glance appears more consistent with expectations. The early Swan Point site is located in the far northwest (central Alaska) while the somewhat later Clovis sites are located south of the southern extent of LGM ice. However, the archeological sites of Meadowcroft Rock shelter in Pennsylvania (Adovasio and Pedler 2004), Page-Ladson in Florida (Webb 2005), Paisley Cave in Oregon (Jenkins 2007), Cactus Hill in Virginia (McAvoy and McAvoy 1997), and Topper in South Carolina (Goodyear 2005) may be nearly contemporaneous in time (or predate) Swan Point (reviewed in Goebel et al. 2008; Dillehay 2009 and references therein). In addition, more 
equivocal and controversial sites such as Hebior and Schaefer (Joyce 2006) also appear to predate Swan Point and are located at the southern margin of the Laurentide ice sheet in the interior of the continent. Such sites suggest, if ultimately confirmed as early human activity areas (Goebel et al. 2008), that human populations were widely distributed throughout much of North America prior to, or coincident with, the opening of an ice-free corridor that would have served as a conduit for human migration. Does this distribution of sites in time and space provide evidence to support or reject the traditional model of American colonization? On its face, the broad distribution of sites across both North and South America would seem to provide evidence against a late entry with rapid colonization. While a number of simulation studies (Anderson and Gillam 2000; Surovell 2000; Moore 2001; Hazelwood and Steele 2003) demonstrate that such a rapid dispersal across the landscape is theoretically feasible, alternative simulation models yield divergent views on what demographic model best accommodates the rapid demographic growth necessarily associated with concomitant rapid migration. Moreover, the alternative simulations are also not concordant with respect to underlying assumptions about the viability of small founding populations, requirements for founding population sizes, migration rates, etc. (Moore and Moseley 2001; Anderson and Gillam 2001). Despite the differences between alternative modeling strategies, such analyses can be quite useful in making predictions about how archeological or genetic research might proceed to test critical aspects of alternative model predictions. In my view, this development has yet to be brought to fruition. Rather, to many, the results of alternative modeling strategies seem to serve to bolster convictions regarding competing colonization models, rather than stimulating direct tests of those models.

An equally interesting and important observation is one that has been well known for some time. The highest density of the distinctive fluted points that define the Clovis tradition is in the eastern United States, essentially along the flanks of the Appalachian mountain range spanning the eastern seaboard (Anderson and Gillam 2000). Why this geographical distribution obtains for this early tool tradition is not clear, but one plausible explanation is that artifact density is correlated with population density. Is the standard colonization model consistent with the development of high population density early in the colonization process on the east coast rather than at a Midwestern point of entry? Anderson and Gillam's simulations (2000) suggest that such a density could be achieved 1,000-2,000 years after initial entry if the colonization was by a "leap-frog" process (long distance population movement subsequent to population fission) rather than the usually assumed "wave-of-advance" model (a continuum-based model incorporating reproduction, mortality, and dispersal parameters), originally pro- posed by Fisher (1937) to describe the wave-of-advance of an advantageous allele in population genetics. However, this contrast has not been effectively tested to date. The answer to such a question requires demographic information or demographic inferences that are often beyond the resolution of the archeological record. But as Delcourt and Delcourt (2004:150) observed, "the archeological evidence supports a founding population for Clovis people that arrived first along the Coastal Atlantic Seaboard...(and) dispersed westward. Whether or not this model is correct, a dilemma still remains. Where was the source of founding populations for Clovis people?" It is possible that alternative approaches to inferring prehistoric demography and population origins may come from alternative data and analytical approaches.

\section{The Genetic Record}

With a few exceptions (Wang et al. 2007; Schroeder et al. 2009; Yang et al. 2010), knowledge of the extent and patterning of genetic variation among Native American populations derives from mitochondrial DNA diversity. It is well documented that five major mtDNA haplogroups characterize indigenous American populations. Based on recent whole mtDNA sequences in modern samples, the five founding haplogroups have been expanded to at least 15 founding lineages (Perego et al. 2010). Even with this number of founding haplotypes in the Americas, Native American populations are characterized by a reduced level of genetic variation compared to other continental populations. This perceived reduction in variation has been assumed to reflect a bottleneck and subsequent reduction in genetic variation at founding. But even here, the signal of reduced genetic variation is somewhat equivocal and the inferences to be drawn from it are not entirely obvious. While the number of mitochondrial types seen in the Americas is reduced relative to global variation, Ward et al. (1991) observed early that sequence variation within groups showed no sign of reduced variation or of a bottleneck. This is somewhat surprising since it might be expected that some reduction in variation would accompany the dramatic reduction in population size that occurred at contact in many populations throughout the Americas. Indeed, it is difficult to determine whether the observed reduction in nuclear variation (circa 7\%, Wang et al. 2007) is the result of a bottleneck at initial colonization or the result of demographic collapse at contact. In any event, the reduction in genetic variation in Native American populations is not as dramatic as often portrayed for either the nuclear genome or mtDNA sequence diversity, although the reduced number of mtDNA haplogroups does appear significant.

Ancient DNA studies may also shed some light on the demographic factors associated with the origin of reduced 
genetic diversity in the Americas. A decade ago, O'Rourke et al. (2000) examined the few population-based aDNA studies conducted in the Americas to that time $(n=6)$ and found that (1) the strong geographic structure apparent in modern populations appeared to be present in the ancient populations studied as well and (2) the diversity observed in the ancient samples was essentially equivalent to the modern populations, at least as measured by nucleotide diversity. More recently, Raff et al. (2011) reexamined this issue by examining over 60 aDNA studies conducted throughout the Americas, the majority based on hypervariable segment (HVSI) sequence data. They note that the signal of geographic structure is still strongly evident in the expanded ancient sample, indicating that the geographic structure that characterizes Native American populations was established several thousands of years ago, based on the antiquity of samples studied genetically. They also note that while nucleotide diversity is low in the ancient samples (comparable to modern population studies), sequence diversity is not reduced and is also comparable to that found in contemporary populations. Thus, the genetic signal for a founding bottleneck, at least with respect to mtDNA is not as clear as often assumed. It is relevant here to observe that Marchani et al. (2007) documented that a reduction in mtDNA haplogroup number can occur over fairly short time frames without extreme reductions in population size or lengthy durations of population size reduction. The conditions under which this result may obtain include a highly geographically structured series of populations and sufficient isolation between them to facilitate local drift.

More recently, Gilbert et al. (2008) provided aDNA evidence for human occupation at Paisley Caves in southern Oregon. Based on aDNA extracted from six presumed human coprolites, Gilbert et al. (2008) identified Native American mtDNA haplogroups A2 and B2, with an age range of approximately $6,500-12,400$ thousand years ago (kya). The aDNA results were confirmed in a separate laboratory, and the dates indicate human presence in the Pacific Northwest prior to the development of Clovis further to the south and east. These results have been questioned (Poinar et al. 2009; Goldberg et al. 2009), although the original authors have responded to the critiques (Gilbert et al. 2009). At present, the results appear to be authentic, certainly cannot be dismissed out of hand, and indicate an early date for human occupation of midlatitude North America.

Similarly, Kemp et al. (2007) reported the aDNA analysis of human remains from the over 10,500 year-old On-Your-Knees Cave site. This individual was found to be mtDNA haplogroup D4h3, a fairly rare haplogroup in the Americas that is nearly limited to Pacific Coastal populations. It is more common in South American populations, and its distribution, including the early occurrence in North America at On-Your-Knees Cave, was instrumental in leading Perego et al. (2009) to postulate two independent migration routes into the Americas fairly early. The coastal distribution of D4h3 was seen as consistent with coastal refugia models of migration during the LGM. It is worth noting that the results of these two aDNA studies provided evidence for the presence of three of the five major Native American haplogroups early in prehistory and are therefore consistent with the inference of Raff et al. (2011) that mtDNA diversity was present and geographically structured early in the colonization process. Smith et al. (2005) assayed mtDNA variation in all of the oldest human remains available for study (e.g., most samples over 7,500 years in age) and found that all of the major mtDNA haplogroups were present except for haplogroup X, confirming the range of mitochondrial diversity early in American populations. The aDNA data are still insufficient to comment on relative population sizes at these times in prehistory.

In a recent series of papers (Tamm et al. 2007; Kitchen et al. 2008; Mulligan et al. 2008), a new and innovative model of American colonization was proposed based on a Bayesian analysis (a statistical approach that permits inference from both data and prior information through conditional probabilities) of genetic variation in Native American populations, the Beringian Pause model. Under this model, a population from Asia migrates onto the Beringian land bridge immediately prior to, or during, the LGM and remains there until retreat of glacial masses opens a corridor east of the Rocky Mountains permitting a southward migration into the interior of an uninhabited continent. According to this model, a stable, or perhaps growing, population existed in central Beringia for 7,000 15,000 years prior to the southern dispersal of $1,000-2,000$ colonists. This is an important set of analyses and inferences partly because of the sophistication of the methods employed, as well as the amount of genetic data used to model the "pause" and subsequent colonization.

But it also raises questions. If a resident population existed in central Beringia for several thousands of years prior to migrating to the interior of the continent, there is surprisingly little archeological evidence of it. There is also another issue that has yet to be adequately addressed. If the Native American gene pool differentiated during an isolated pause in Beringia, we must expect that all of the founding mtDNA haplotypes were present at polymorphic frequencies in this source population. Yet only haplotypes associated with haplogroups $\mathrm{A}$ and $\mathrm{D}$ are present in this core area today, and as far as ancient DNA data can speak to the issue, it has been so for a very long time (Raff et al. 2011). What demographic scenario can account for the absence of the majority of founding haplotypes in the core 
area of the proposed source population? Such a result is counter, for example, to the logic offered by many geneticists for a source population in southern Siberia or Mongolia on the grounds that it is that geographic region in Asia where the majority of mtDNA haplogroups most closely related to Native American ones are found at moderate frequencies (Merriwether et al. 1996; Kolman et al. 1996).

An additional concern is the size and rate of migration of such a single population colonization model. Using forward simulation, Fix (2002) argued that the observed geographic pattern of population differentiation in mtDNA haplotypes, as measured by $F_{\mathrm{st}}$, could not be recovered if the colonization was accomplished by a single migrant population after the LGM. However, an earlier colonization, which provides additional time for population differentiation to accrue or a separate coastal migration, was sufficient to account for the observed $F_{\text {st }}$ values among contemporary Native American populations (Fix 2005). This result suggests that there was insufficient time from the end of the LGM for a single population to disperse and differentiate to the degree necessary to account for the modern geographic structure of mtDNA haplogroup frequencies. In this regard, the result of Fix's colonization simulation based on mtDNA data (2003) is not concordant with the simulations of colonization based on archeological data (Anderson and Gillam 2000; Surovell 2000). It is useful to recall that there is evidence that the striking geographic structure in mtDNA haplogroup frequencies in the Americas was established several thousand years before present (O'Rourke et al. 2000; Raff et al. 2011), shortening even more the temporal span over which such differentiation must have developed if it is constrained by the terminal LGM; presumably further weakening the argument for a single, late colonizing population as the primary source for later Native American populations (Volodko et al. 2008).

For a time, it appeared that the Bayesian skyline plot of population size and population growth, that provided support for the Beringian Pause model, was replicated and confirmed in a statistical analysis of radiocarbon dates of Eurasian and Beringian archeological sites. Hamilton and Buchanan (2010) used diffusion methods to study the age range and geographical distribution of archeological sites to infer two periods of dramatic population growth (expansion) that correlated with the two periods of growth inferred by Kitchen et al. (2008) based on mtDNA sequence data. One occurred during an early period of Asian residency and slow movement eastward, and a subsequent one was inferred that correlated with the rapid dispersal and population growth during the migration into the interior of North America at the end of the LGM. However, it became clear that some errors of classification of the samples in the original genetic analysis required correction Fagundes et al. (2008a), and a subsequent analysis (Mulligan et al. 2008) using a corrected and expanded Native American genetic dataset revealed only a single period of population growth, coincident with the end of the LGM. This result implied that the Beringian population must have remained small throughout its period of residence, which is more consistent with the archeological record, but is more problematic for maintenance of adequate genetic variation to characterize the subsequent founding population of the Americas. In any event, it appears once again that the genetic and archeological data and analyses are discordant with respect to key elements of early demographic parameters of colonizing populations.

Finally, it is necessary to consider briefly coalescent estimates for the "origin" of mtDNA lineages. A large number of investigators have examined mtDNA sequence diversity, both for the HVSI and for whole mtDNA genomes, and have estimated the coalescent of these lineages. Most such estimates are in the 14,000-18,000year range, implying that this is the time frame when all of the Native American mtDNA haplogroups became distinct from their Asian ancestral lineages. Two cautions need to be mentioned. First, although these coalescent estimates are sometimes assumed to represent colonization times, there is in fact, no geographic information contained in them. Thus, where the populations were located at the time of coalescence is open to speculation. Almost assuredly, they were not yet in the Americas, since all founding haplotypes are essentially unique to American populations (although closely related to Asian ancestral lineages), yet are widely distributed in the Americas. The location of ancestral populations at the time of coalescence could be in Beringia (during the pause?), farther west in northeast Siberia, or even in the earlier hypothesized ancestral region of southcentral Siberia/northern Mongolia. If the ancestral population was sufficiently isolated, it could have remained in its location for a long period of time before descendants entered the American landscape. Under this view, the uniformity of coalescent dates near the end of the LGM would seem to support a late, single population colonization model.

The second caution, however, calls into question the reliability of dating coalescent events. Cox (2008) showed convincingly that when coalescent estimates are based on the rho $(\rho)$ statistic, they are subject to a systematic bias. This statistic is the mean number of polymorphisms (e.g., base substitutions) observed across a number of independent lineages, weighted by sample size, that derive from a genealogically defined common ancestor. Under conditions of subdivision, geographic structure, rapid growth, etc. (demographic characteristics describing early colonizing populations), the coalescent estimates are generally, but not always, underestimates of the true coalescent dates. A majority of mtDNA coalescent estimates have been 
obtained using the rho statistic and may likely, therefore, be underestimates of the real time frame for the origin of the Native American gene pool and should be considered minimum estimates. In many simulations (Cox 2008), the real coalescent value was actually outside the $95 \%$ CI of the estimate, suggesting that we should reevaluate both the accuracy and significance of most coalescent estimates. It is no longer clear that they so strongly support a late entry and dispersal model for American colonization. Indeed, several investigators have obtained estimates in the 20,000-30,000year range (Forster et al. 1996; Torroni et al. 1994; Bonatto and Salzano 1997; Volodko et al. 2008), reviewed in Goebel et al. (2008).

\section{Paleoecology}

\section{The Last Glacial Maximum}

Reconstruction of past environments, through which migrants must have lived and transited, is crucial to the context of colonization models. In the case of the initial colonization of the Americas, this often means the timing and placement of glacial ice sheets during the LGM. Our knowledge of the development, duration, and demise of continental ice during the LGM has been refined considerably in recent years but is still far less precise than we often assume, based as it is on estimations from diverse predictive models of climate and climate change (Mason et al. 2001).

The traditional view is that two large continental glaciers, the Cordilleran and Laurentide, covered all of northern North America until the end of the LGM, approximately 14,000 before present (BP). The retreat of these glacial masses opened a corridor between them at the end of the LGM through which the earliest migrants moved to colonize the rest of the hemisphere. In this view, extension of the Laurentide ice sheet to the northeast constituted the Innuitian ice sheet that made the North American glacial masses continuous with the Greenland ice sheet, effectively sealing the Americas from Asia for several millennia. The traditional "Clovis first" model, the genetic-based "Beringian Pause" model, and indeed any late, single entry colonization model relies on the presumed impermeability of the North American glacial masses until the end of the LGM.

There is evidence, however, that the North American glacial masses during the LGM may have been less monolithic and somewhat more porous to human transit, at least at the margins (both temporally and geographically), than generally assumed. The traditional view of the placement of ice during the LGM derived in large measure from the landmark Climate: Long range Investigation, Mapping, and Prediction (CLIMAP) project of the late 1970s and early 1980s that estimated ice extent from observations on sea surface temperatures, glacial ice, and albedo (CLIMAP 1981, Denton and Hughes 1981). CLIMAP models included both a maximum and minimum model of glacial extent; the former was associated with a sea level decline at LGM of 163 meters while the minimum model predicted a sea level decline of 127 meters (Denton and Hughes 1981). More recent work on sea level fluctuations indicates a maximum sea level drop of circa 130 meters (Clark and Mix 2002; Dyke et al. 2002), suggesting that the CLIMAP minimum ice model is more consistent with observed sea level variation during the LGM. But most discussions and illustrations of the North American ice sheets characterize the more extensive glacial development associated with the maximum CLIMAP model. Moreover, a majority of paleoecological records show a drastic drop in sea level prior to $25 \mathrm{kya}$, with most of the rest of sea level decline by 20 kya. Thus, most of the decline in sea level occurred prior to the LGM. This result is important to the colonization debate for several reasons, not least of which is an emergence of an expanded coastal plain prior to the maximum growth of continental glaciers.

The assumption that the North American glacial masses grew and declined in tandem is less tenable than it once was. Dyke et al. (2002) reconstructed the development of the Laurentide ice sheet, and concluded that while it was initiated prior to 25,000 radiocarbon years $\left({ }^{14} \mathrm{C}\right) \mathrm{BP}$, it reached its continental maximum in the northwest, northeast and south by $23,000{ }^{14} \mathrm{C} \mathrm{BP}$, but not until $20,000{ }^{14} \mathrm{C} \mathrm{BP}$ in the southwest and far north. Thus, the approach of the Laurentide ice sheet to the growing Cordilleran ice mass was later than typically assumed. Moreover, these investigators suggest that the glaciations of the northern arctic archipelago (the Innuitian ice sheet) developed later in the glacial cycle, and there is some ambiguity as to whether it completely covered all landmasses in the region. There is little evidence, for example, for glacial ice along stretches of the Central Canadian arctic coast. While the southern portion of Baffin Island appears to have been fully glaciated (Dyke et al. 2002; Clark and Mix 2002), the record for the northern portion of the island is less clear, with coastal uplands north of Cumberland Sound apparently remaining ice free, except for glaciers moving down fjords (Miller et al. 2002, but see Dyke 2004). Moreover, the somewhat later development of the Cordilleran glacier (after 19,000-20,000 years ago) suggests that interior terrain between the two continental glaciers may have remained open longer than generally assumed in the north, with the late LGM appearance of the ice-free corridor in the south preceding that in the north (Dyke 2004). Some simulations have also suggested that the coalescence of the two large continental glaciers was not continuous but intermittent, with interior refugia persisting throughout the LGM (Barendregt and Duk-Rodkin 2004; 
Catto et al. 1996). This is relevant to colonization models as it raises the possibility that both coastal and interior routes of travel around or through glacial masses may have been possible until after 20,000 ${ }_{14} \mathrm{C}$ BP. If the origin of the Native American gene pool actually dates to a time period earlier than the oft-cited 18-14 kya, then migrants may well have had multiple points of entry to the Americas at an appropriate time prior to the LGM. If eastern Baffin Island escaped Late Wisconsinan glaciation (Dyke et al. 2002; Miller et al. 2002), then alternative routes into the Americas may well have been available throughout the LGM (e.g., O’Rourke and Raff 2010).

The possibility that ice edge margins in the high arctic and along the west coast of the Cordilleran glacial mass (or even in the interior) were discontinuous supports the hypothesis that glacial refugia existed, at least for some periods of the LGM, in both regions. Such refugia are compatible with human occupation. There is little current evidence for human occupation in the high arctic of Canada during the LGM, but a wealth of data on other species confirms that biotically rich refugia existed in the area and could have provided some resource patches for human populations (Shafer et al. 2010; Rock ptarmigan, Holder et al. 1999; arctic grayling, Stamford and Taylor 2004; collared lemming, Federov and Stenseth 2002). The Northwest Coast refugia are better documented (e.g., Haida Gwaii) and have been instrumental in recent suggestions for an early coastal migration route to the west coast of the Americas (Dixon 1999; Kemp et al. 2007; Dillehay et al. 2008, Erlandson et al. 2011), an archeological perspective supported by several genetic studies (e.g., Fix 2002; 2005; Fagundes et al. 2008a, b). Loehr et al. (2006) also inferred evidence for two interior refugia between the Corilleran and Laurentide ice sheets from mtDNA sequence data from two species of mountain sheep, supporting the lack of continuous glacier coalescence postulated by Barendregt and Duk-Rodkin (2004) and Catto et al. (1996).

It is also worth noting in this context that there is little evidence for the presence of glaciers in northern Siberia during the last glacial advance except west of Novya Zemlya and at the tip of the Taimyr peninsula associated with the Fenno-Scandian ice sheet, and some glacial development in the Verkoyask Mountains of northeast Siberia (Mangerud et al. 2002, but see Grosswald and Hughes 2002). Thus, glacial ice was not a particular impediment to human travel in the Siberian arctic during the LGM. It is obvious that people were exploiting arctic coastal, or near-coastal, resources early on, with archeological sites dating to between 30,000 and 40,000 years ago in the Russian arctic (e.g., Pitulko et al. 2004; Pavlov et al. 2001). Nevertheless, archeological evidence for human occupation of interior northeast Siberia from the onset of the LGM over 25 kya until initiation of glacial retreats is effectively absent (Goebel et al. 2003). This suggests that an interior population for the source of the Beringian Pause population is also absent, or nearly so, from the geographic region where we might expect to find it.

\section{Pathogens as Human Proxies}

An independent line of evidence that might contribute to our knowledge of human migrations to the Western Hemisphere comes from obligate human pathogens. The distribution of such organisms in modern populations should reflect their origin and colonization of new areas as much as their human hosts. Falush et al. (2003) examined DNA sequence diversity in a series of housekeeping and virulence genes in a global collection of Helicobacter pylori isolates. H. pylori is a Gram-negative bacterium that colonizes the human gut. Often a benign pathogen, $H$. pylori is also associated with increased risk of stomach ulcers and cancer in some individuals. Unsurprisingly, sequence analysis of $H$. pylori among Native American samples reveals close phylogenetic association with East Asian lineages of the bacterium, reflecting the origin of this pathogen in the Americas coincident with colonization of the Americas from Asia (see also Moodley and Linz 2009). Unlike the case in other colonizing populations (e.g., Polynesians), the sequence diversity in Native American colonies of $H$. pylori shows no evidence for the effect of drift (Falush et al. 2003), i.e., no reduction in variation due to founder effect. Rather, the authors suggest that the genetic evidence from $H$. pylori in the Western Hemisphere indicates that either the bacterium accompanied large numbers of colonizing Native Americans (including Eskimo/Inuits) or was independently introduced on numerous occasions. Either scenario is consistent with the exclusive origin of Native Americans from an Asian source but inconsistent with a small, single founding population.

\section{Summary and Conclusions}

Accumulating evidence suggests that the first migrants to the Americas may have arrived via multiple routes and at different times - before, during, and immediately after the LGM - rather than as a single, small colonizing population. The precise timing of any of these migration events, exact geographic routes followed, or even size of individual colonizing groups remains obscure. It seems clear that population size for any individual migrant group was small, but collectively it may not have been. Thus, estimating a founding population size is less precise than often presumed. Many estimates of interest with respect to colonization (population size and time of migration) derive from 
sophisticated models in genetics, archeology, demography or climatology, and the accuracy of the estimates is closely linked to the assumptions and parameters of the generating model. Subtle changes to model parameters can yield widely divergent estimates from the same data (Hey 2005; Kitchen et al. 2008). Similarly, estimation of timing of the origin of the Native American genome requires careful attention to both estimation methods (e.g., Cox 2008) and calibration of molecular evolution rates (Ho and Endicott 2008; Endicott and Ho 2008; Fagundes et al. 2008b; Henn et al. 2008). Given the greater resolution afforded especially by the expanding molecular genetic record of Native American populations, it is still not clear that we can distinguish between a single founding population and several founding groups that derive from a common source population.

The past decade has seen an avalanche of new data from archeology, genetics, phylogeography, and paleoecology that has provided challenges to our traditional view of American colonization. That new data challenges old inferences does not mean our older conceptions are entirely incorrect. Rather, I suggest that some older views are in need of revision and some of the newer and more provocative results and inferences drawn from them require confirmation from other lines of evidence. We should be particularly attentive to the propensity to draw firm conclusions from only a single perspective or data array. Many of our traditional-some would say cherished-belifs about source, timing, and routes of migrants to the Western Hemisphere should properly be viewed as hypotheses to be rigorously tested rather than received wisdom. New data from sources unavailable in previous decades is rapidly accumulating in fields as diverse as human and nonhuman genetic diversity, isotope analyses, archeology and paleoecology, such that powerful tests of these hypotheses are now, or soon will be, directly testable. This is not a trivial academic exercise. Many of the more high-profile problems in human evolution relate to the types of migration models and underlying data discussed in this issue - early human dispersal from Africa and the subsequent colonization of the remaining inhabited continents. Identifying and quantifying rates of admixture between colonizing modern humans and resident archaic populations is also of considerable interest. As the last major continents to be colonized by modern humans, without the complication of early admixture with existing populations, and with enviable archeological, genetic, and environmental records, the Americas are the best test case for identifying signatures of colonization, settlement, population growth, and subsequent dispersal. If we are unable to clearly identify signals of such events here, we have little power to convince ourselves or others that we can do so reliably in earlier contexts. Fortunately, in my view, both the data and analytical tools have been refined in recent years to mount a more complex and nuanced examination of American colonization. We are on the cusp of a new horizon with respect to our understanding of the circumstances of origin of the first Americans.

\section{References}

Achilli A, Perego UA, Bravi CM, Coble MD, Kong QP, Woodward $\mathrm{SR}$, et al. The phylogeny of the four Pan-American mtDNA haplogroups: implications for evolutionary and disease studies. PLoS ONE. 2008;3:e1764.

Adovasio JM, Pedler DR. Pre-Clovis sites and their implications for human occupation before the Last Glacial Maximum. In: Madsen DM, editor. Entering America: Northeast Asia and Beringia before the Last Glacial Maximum. Salt Lake City: Univ. of Utah Press; 2004. p. $139-58$

Alfimov AV, Berman DI. Beringian climate during the Late Pleistocene and Holocene. Quat Sci Rev. 2001;20:127-34.

Anderson DG, Gillam JC. Paleoindian colonization of the Americas: implications from an examination of physiography, demography, and artifact distribution. Am Antiq. 2000;65:43-66.

Anderson DG, Gillam JC. Paleoindian interaction and mating networks: reply to Moore and Moseley. Am Antiq. 2001;66:530-5.

Barendregt RW, Duk-Rodkin A. Chronology and extent of Late Cenozoic ice sheets in North America: a magnetostratigraphic assessment. In: Ehlers J, Gibbard PL, editors. Quaternary glaciations - extent and chronology, part II. Amsterdam: Elsevier; 2004. p. 1-7.

Bonatto SL, Salzano FM. Diversity and age of the four major mtDNA haplogroups, and their implications for the peopling of the New World. Am J Hum Genet. 1997;61(6):1413-23.

Catto NR, Liverman DGE, Bobrowsky PT, Rutter N. Laurentide, Cordilleran, and Montane glaciation in the Western Peace RiverGrande Prarie Region, Alberta and British Columbia, Canada. Quat Int. 1996;32:21-32.

Clark PU, Mix AC. Ice sheets and seal level of the Last Glacial Maximum. Quat Sci Rev. 2002;21:1-7.

CLIMAP (1981) Seasonal reconstruction of the earth's surface at the last glacial maximum. Geol. Soc. Amer. Map and Chart series, C36.

Cox MP. Accuracy of molecular dating with the rho statistic: deviations from coalescent expectations under a range of demographic methods. Hum Biol. 2008;80:335-57.

Delcourt PA, Delcourt HR. Prehistoric Native Americans and ecological change: human ecosystems in eastern North America since the Pleistocene. Cambridge: Cambridge University Press; 2004.

Denton GH, Hughes TJ, editors. The last great ice sheets. New York: Wiley; 1981.

Dillehay TD. Monte Verde: a Late Pleistocene settlement in Chile, volume 2 , the archaeological context and interpretation. Washington: Smithsonian Institution Press; 1997.

Dillehay TD. Probing deeper into first American studies. Proc Natl Acad Sci USA. 2009;106:971-8.

Dillehay TD, Ramírez C, Pino M, Collins MB, Rossen J, PinoNavarro JD. Monte Verde: seaweed, food, medicine, and the peopling of South America. Science. 2008;320:784-6.

Dixon EJ. Bones, boats and bison: archaeology and the first colonization of Western North America. Albuquerque: University of New Mexico Press; 1999.

Dixon EJ. Human colonization of the Americas: timing, technology and process. Quat Sci Rev. 2001;20:277-99.

Dyke AS. An outline of North American deglaciation with emphasis on central and Northern Canada. In: Ehlers J, Gibbard PL, 
editors. Quaternary glaciations - extent and chronology, part II. Amsterdam: Elsevier; 2004. p. 373-424.

Dyke AS, Andrews JT, Clark PU, England JH, Miller GH, Shaw J, et al. The Laurentide and Innuitian ice sheets during the Last Glacial Maximum. Quat Sci Rev. 2002;21:9-31.

Endicott P, Ho SY. A Bayesian evaluation of human mitochondrial substitution rates. Am J Hum Genet. 2008;82:895-902.

Erlandson JM, Rick TC, Braje TJ, Casperson M, Culleton B, Fulfrost $\mathrm{B}$, et al. Paleoindian seafaring, maritime technologies, and coastal foraging on California's Channel Islands. Science. 2011;331:1181-5.

Fagundes NJR, Kkanitz R, Eckert R, Valls ACS, Bogo MR, Salzano FM, et al. Mitochondrial population genomics supports a single pre-Clovis origin with a coastal route for the peopling of the Americas. Am J Hum Genet. 2008a;82:583-92.

Fagundes NJR, Kanitz R, Bonatto SL. Reply to Ho and Endicott. Am J Hum Genet. 2008b;83:127-47.

Falush D, WirthT LB, Pritchard JK, Stephens M, Kidd M, Blaser MJ, et al. Traces of human migrations in Helicobacter pylori populations. Science. 2003;299:1582-5.

Fedorov VB, Stenseth NC. Multiple glacial refugia in the North American Arctic: inference from phylogeography of the collared lemming (Dicrostonyx groenlandicus). Proc R Soc Lond B Biol Sci. 2002;269:2071-7.

Fisher RA. The wave of advance of advantageous genes. Ann Eugen. 1937;7:355-69.

Fix AG. Colonization models and initial genetic diversity in the Americas. Hum Biol. 2002;74:1-10.

Fix AG. Rapid deployment of the five founding Amerind mtDNA haplogroups via coastal and riverine colonization. Am J Phys Anthropol. 2005;128:430-6.

Forster P, Harding R, Torroni A, Bandelt H-J. Origin and evolution of Native American mtDNA variation: a reappraisal. Am J Hum Genet. 1996;59:935-45.

Gilbert MTP, Jenkins DL, Götherstrom A, Naveran N, Sanchez JJ, et al. DNA from pre-Clovis human coprolites in Oregon, North America. Science. 2008;320:786.

Gilbert MTP, Jenkins DL, Higham TFG, Rasmussen M, Malmström $\mathrm{H}$, et al. Response to comment by Poinar et al. On "DNA from pre-Clovis human coprolites in Oregon, North America". Science. 2009;325:148b.

Goebel T, Waters MR, Dikova MA. The archaeology of Ushki Lake, Kamchatka, and the Pleistocene peopling of the Americas. Science. 2003;301:501-5.

Goebel T, Waters MR, O'Rourke DH. The Late Pleistocene dispersal of modern humans in the Americas. Science. 2008;319:1497502 .

Goldberg P, Berna F, Macphail RI. Comment on "DNA from PreClovis human coprolites in Oregon, North America". Science. 2009;325:148c.

Gonzalez-Jose R, Bortolini MC, Santos FR, Bonatto SL. The peopling of America: craniofacial shape variation on a continental scale and its interpretation from an interdisciplinary view. Am J Phys Anthropol. 2008; 137:175-87.

Goodyear AC (2005) Legacy: South Carolina Institute of Archaeology and Anthropology 9-1/2, 1.

Grosswald MG, Hughes TJ. The Russian component of an Arctic ice sheet during the Last Glacial Maximum. Quat Sci Rev. 2002;21:121-46.

Hamilton MJ, Buchanan B. Archaeological support for the three-stage expansion of modern humans across Northeastern Eurasia and into the Americas. PLoS ONE. 2010;5(8):e12472. doi:10.1371/ journal.pone.0012472.

Hazelwood L, Steele J. Spatial dynamics of human dispersals: constraints on modeling and archaeological validation. $\mathrm{J}$ Archaeol Sci. 2003;31:669-79.
Henn BM, Gignoux CR, Feldman MW, Mountain JL. Characterizing the time dependency of human mitochondrial DNA mutation rate estimates. Mol Biol Evol. 2008;26:217-30.

Hey J. On the number of New World founders: a population genetic portrait of the peopling of the Americas. PLoS Biol. 2005;3(6): e193.

Ho SY, Endicott P. The crucial role of calibration in molecular date estimates for the peopling of the Americas. Am J Hum Genet. 2008;83:142-6. author reply 146-147.

Holder K, Montgomerie R, Friesen VL. A test of the glacial refugium hypothesis using patterns of mitochondrial and nuclear DNA sequence variation in rock ptarmigan (Lagopus mutus). Evolution. 1999;53:1936-50.

Holmes CE and Crass BA (2003) paper presented at the 30th annual meeting of the Alaska Anthropological Association, Fairbanks, 27-29 March.

Jenkins DL. In: Graf KE, Schmitt DN, editors. Paleoindian or Paleoarchaic? Great Basin human ecology at the Pleistocene/ Holocene transition. Salt Lake City: Univ. of Utah Press; 2007. p. $57-81$.

Joyce DJ. Chronology and new research on the Schaefer mammoth (? Mammuthus primigenius) site, Kenosha County, Wisconsin, USA. Quat Int. 2006;142-143:44-57.

Kemp BM and Schurr TG. 2010. Ancient and modern genetic variation in the Americas. In Human Variation in the Americas, edited by Benjamin M. Auerbach. Center for Archaeological Investigations, Occasional Paper No. 38.

Kemp BM, Malhi RS, McDonough J, Bolnick DA, Eshleman JA, et al. Genetic analysis of Early Holocene skeletal remains from Alaska and its implications for the settlement of the Americas. Am J Phys Anthropol. 2007;132:605-21.

Kitchen A, Miyamoto MM, Mulligan CJ. A three-stage colonization model for the peopling of the Americas. PLoS ONE. 2008;3(2): e1596.

Kolman C, Sambuughin N, Bermingham E. Mitochondrial DNA analysis of Mongolian populations and implications for the origin of New World founders. Genetics. 1996;142:1321-34.

Loehr J, Worley K, Grapputo A, Carey J, Veitch A, Coltman DW. Evidence for cryptic glacial refugia from North American mountain sheep mitochondrial DNA. J Evol Biol. 2006;19:419 30.

Madsen DB, editor. Entering America: Northeast Asia and Beringia before the Last Glacial Maximum. Salt Lake City: University of Utah Press; 2004.

Mangerud J, Astakhov V, Svendsen J-I. The extent of the BarentsKara Ice Sheet during the Last Glacial Maximum. Quatern Sci Rev. 2002;21:111-9.

Marchani EE, Rogers AR, O'Rourke DH. The Thule migration: rejecting population histories using computer simulation. Am J Phys Anthropol. 2007;131(2):281-4.

Marshall SJ, James TS, Clarke GKC. North American ice sheet reconstructions at the Last Glacial Maximum. Quat Sci Rev. 2002;21:175-92.

Mason OK, Bowers PM, Hopkins DM. The early Holocene Milankovitch thermal maximum and humans: adverse conditions for the Denali complex of eastern Beringia. Quat Sci Rev. 2001;20:525-48.

McAvoy JM and McAvoy LD, eds. (1997) Archaeological investigations of site 44SX202, Cactus Hill, Sussex County, Virginia, Virginia Department of Historic Resources, Research Report Series No. 8, Richmond.

Meltzer DJ. First peoples in a New World: colonizing Ice Age America. Berkeley: University of California Press; 2009.

Merriwether DA et al. mtDNA variation indicates Mongolia may have been the source for the founding population of the New World. Am J Hum Genet. 1996;59:204-12. 
Miller GH, Wolfe AP, Steig EJ, Sauer PE, Kaplan MR, Briner JP. The Goldilocks dilemma: big ice, little ice, or "just-right" ice in the Eastern Canadian arctic. Quat Sci Rev. 2002;21:33-48.

Moodley Y, Linz B. Helicobacteer pylori sequences reflect past human migrations. Genome Dyn. 2009;6:62-74.

Moore JH. Evaluating five models of human colonization. Am Anthropol. 2001;103:395-408.

Moore JH, Moseley ME. How many frogs does it take to leap around the Americas? Comments on Anderson and Gillam. Am Antiq. 2001;66:526-9.

Mulligan CJ, Kitchen A, Miyamoto MM. Updated three-stage model for the peopling of the Americas. PLoS ONE. 2008;3(9):e3199.

O'Rourke DH, Raff JA. The human genetic history of the Americas: the final frontier. Curr Biol. 2010;20:R202-7.

O'Rourke DH, Hayes MG, Carlyle SW. Spatial and temporal stability of mtDNA haplogroup frequencies in native North America. Hum Biol. 2000;72:15-34.

Pavlov P, Svendsen JI, Indrelid S. Human presence in the European Arctic nearly 40,000 years ago. Nature. 2001;413:64-7.

Perego UA, Achilli A, Angerhofer N, Accetturo M, Pala M, Olivieri A, et al. Distinctive but concomitant Paleo-Indian migration routes from Beringia marked by two rare mtDNA haplogroups. Curr Biol. 2009;19:1-8.

Perego UA, Angerhofer N, Pala M, Olivieri A, Lancioni H, et al. The initial peopling of the Americas: a growing number of founding mitochondrial genomes from Beringia. Genome Res. 2010;20 (9):1174-9.

Perez SI, Bernal V, Gonzalez PN, Sardi M, Politis GG. Discrepancy between cranial and DNA data of early Americans: implications for American peopling. PLoS ONE. 2009;4(5):e5746. doi:10.1371/journal.pone.0005746.

Pitulko V, Nikolski P, Girya E, Basilyan E, Tumskoy V, Koulakov S, et al. The Yana RHS site: humans in the Arctic before the Last Glacial Maximum. Science. 2004;303:52-6.

Poinar H, Fidel S, King CE, Devault AM, Bos K, Kuch M, et al. Comment on "DNA from Pre-Clovis human coprolites in Oregon, North America". Science. 2009;325:148a.

Pucciarelli HM, Neves WA, González-José R, Sardi ML, Rozzi FR, Struck A, et al. East-West cranial differentiation in preColumbian human populations of South America. J Comp Hum Biol. 2006;57:133-50.

Raff JA, Bolnick DA, Tackney J, and O'Rourke DH (2011) Ancient DNA perspectives on American colonization and population history (in press)
Schroeder KB, Jakobsson M, Crawford MH, Schurr TG, Boca SM, et al. Haplotypic background of a private allele at high frequency in the Americas. Mol Biol Evol. 2009;26:995-1016.

Shafer AB, Cullingham CI, Côté SD, Coltman DW. Of glaciers and refugia: a decade of study sheds new light on the phylogeography of northwestern North America. Mol Ecol. 2010;19:4589-621.

Siddall M, Rohling EJ, Thompson WG, Waelbroeck. Marine isotope stage 3 sea level fluctuations: data synthesis and new outlook. Rev Geophys. 2008;46:RG4003.

Smith DG, Malhi RS, Eshleman JA, Kaestle FA, Kemp BM. Mitochondrial DNA haplogroups of Paleoamericans in North America. In: Bonnichsen R, Lepper BT, Stanford D, Waters MR, editors. Paleoamerican origins: beyond Clovis. College Station: Texas A\&M University Press; 2005. p. 243-54.

Stamford MD, Taylor EB. Phylogeographical lineages of Arctic grayling (Thymallus Arcticus) in North America: divergence, origins and affinities with Eurasian Thymallus. Mol Ecol. 2004;13:1533-49.

Surovell TA. Early Paleoindian women, children, mobility, and fertility. Am Antiq. 2000;65:493-508.

Tamm E, Kivisild T, Reidla M, Metspalu M, Smith DG, Mulligan CJ, et al. Beringian standstill and spread of Native American founders. PLOS ONE. 2007;2:e829.

Torroni A, Neel JV, Barrantes R, Schurr TG, Wallace DC. Mitochondrial DNA "Clock" for the Amerinds and its implications for timing their entry into North America. Proc Natl Acad Sci USA. 1994;91:1158-62.

Volodko NV, Starikovskaya EB, Mazunin IO, Eltsov NP, Naidenko P, Wallace DC, et al. Mitochondrial genome diversity in Arctic Siberians with particular reference to the evolutionary history of Beringia and Pleistocenic peopling of the Americas. Am J Hum Genet. 2008;82:1084-100.

Wang S, Lewis CM, Jakobsson M, Ramachandran S, Ray N, et al. Genetic variation and population structure in Native Americans. PLoS Genet. 2007;3(11):e185.

Ward $\mathrm{R}$ et al. Extensive mitochondrial diversity within a single Amerindian tribe. Proc Natl Acad Sci USA. 1991;88(19):8720-4.

Waters MR, Stafford Jr TW. Redefining the Age of Clovis: implications for the peopling of the Americas. Science. 2007;315:1122-6.

Webb SD, editor. First Floridians and last Mastodons: the PageLadson Site in the Aucilla River. Dordrecht: Springer; 2005.

Yang NN, Mazieres S, Bravi C, Ray N, Wang S, Burley M-W, et al. Contrasting patterns of nuclear and mtDNA diversity in Native American populations. Ann Hum Genet. 2010;74(6):525-38. 